1 Modulation of $\mathrm{IP}_{3}$ receptor stability and its implication in

2

3

5

6

7

8

9

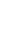
\section{cell death and disease}

\author{
Bruno Seitaj, Geert Bultynck ${ }^{\#}$, Hristina Ivanova
}

KU Leuven, Laboratory of Molecular \& Cellular Signaling, Dep. Cellular and Molecular Medicine,

Campus Gasthuisberg O/N-I bus 802, Herestraat 49, B-3000 Leuven, Belgium

\# correspondence to: Geert Bultynck; tel: +32-16-330215; email: geert.bultynck@kuleuven.be 


\section{Abstract}

$2 \mathrm{Ca}^{2+}$ is a ubiquitous and versatile second messenger, which is important for processes like cell 3 death and survival. Intracellular $\mathrm{Ca}^{2+}$ dynamics are tightly controlled by several $\mathrm{Ca}^{2+}$-transport 4 systems. The main intracellular $\mathrm{Ca}^{2+}$-release channel is inositol 1,4,5-trisphosphate ( $\mathrm{IP}_{3}$ ) 5 receptor $\left(\mathrm{IP}_{3} \mathrm{R}\right)$, which is responsible for the $\mathrm{Ca}^{2+}$ flux from the endoplasmic reticulum. $\mathrm{IP}_{3} \mathrm{R}$ 6 dysfunction has been implicated in various pathological conditions including cancer and 7 neurodegenerative diseases. Hence, $\mathrm{IP}_{3} \mathrm{Rs}$ function at the common cross-point of different pro8 survival and cell-death signaling pathways and are targeted by several proteins. A number of 9 protein modifications directly impact $\mathrm{IP}_{3} \mathrm{R}$ gating and thus $\mathrm{Ca}^{2+}$-flux properties. Yet, several regulating mechanisms emerged to regulate total $\mathrm{IP}_{3} \mathrm{R}$ levels by altering $\mathrm{IP}_{3} \mathrm{R}$ stability and turnover through proteasomal degradation and protease cleavage. In the present review, we will highlight the mechanisms and the impact of (i) $\mathrm{IP}_{3} \mathrm{R}$ ubiquitination and the following proteasomal degradation and (ii) $\mathrm{IP}_{3} \mathrm{R}$ cleavage by two major classes of proteases, namely caspases and calpains. 


\section{Intracellular $\mathrm{Ca}^{2+}$ signaling: $\mathrm{IP}_{3} \mathrm{R}$ as a key player}

$2 \mathrm{Ca}^{2+}$ plays a fundamental role in a plethora of physiological processes, including secretion, muscle contraction, mitochondrial bioenergetics, cell proliferation and cell death in virtually all cell types (Berridge et al., 2000; Clapham, 2007). These divergent functions of $\mathrm{Ca}^{2+}$ signals are governed by the complex spatiotemporal organization. $\mathrm{Ca}^{2+}$ signals can appear as transient $\mathrm{Ca}^{2+}$ elevations (such as pro-survival $\mathrm{Ca}^{2+}$ oscillations, which boost mitochondrial energetics) or as sustained $\mathrm{Ca}^{2+}$ elevations (such as pro-apoptotic $\mathrm{Ca}^{2+}$ events) (Berridge, 2007; Berridge et al., 2003). Furthermore, $\mathrm{Ca}^{2+}$ rises can propagate throughout the cell or they can occur in localized microdomains (La Rovere et al., 2016). $\mathrm{Ca}^{2+}$ microdomains result from the apposition of different intracellular $\mathrm{Ca}^{2+}$ stores, like endoplasmic reticulum (ER), mitochondria, lysosomes, etc or of these organelles with the plasma membrane (Raffaello et al., 2016).

The intracellular $\mathrm{Ca}^{2+}$ homeostasis is tightly modulated by the interplay between a variety of $\mathrm{Ca}^{2+}$ transport systems, $\mathrm{Ca}^{2+}$ binding proteins and their regulators. The majority of intracellular $\mathrm{Ca}^{2+}$ is accumulated in the ER, where it is buffered by $\mathrm{Ca}^{2+}$-binding proteins like calreticulin, calnexin and calsequestrin (Prins and Michalak, 2011). $\mathrm{Ca}^{2+}$ is transported into the ER by the sarco/endoplasmic reticulum $\mathrm{Ca}^{2+}$ ATPase (Vandecaetsbeek et al., 2011). This $\mathrm{ER} \mathrm{Ca}^{2+}$ uptake is counteracted by $\mathrm{Ca}^{2+}$-leak and -release mechanisms. Upon cell stimulation with hormones, neurotransmitters or antibodies, $\mathrm{Ca}^{2+}$ is mobilized and released into the cytosol through inositol 1,4,5-trisphosphate $\left(\mathrm{IP}_{3}\right)$ receptors $\left(\mathrm{IP}_{3} \mathrm{Rs}\right)$ (Fedorenko et al., 2014). The ubiquitously expressed $\mathrm{IP}_{3}$ Rs function as tetrameric channels that mediate $\mathrm{Ca}^{2+}$ fluxes from the ER upon activation by $\mathrm{IP}_{3}$ (Foskett et al., 2007; Mikoshiba, 2015). In addition to the ER, IP 3 Rs are also present in the nuclear envelope, Golgi apparatus, secretory vesicles and even the plasma membrane (Taylor et al., 1999; Thillaiappan et al., 2017). At the level of the ER, $\mathrm{IP}_{3} \mathrm{Rs}$ are not equally distributed and depending on their exact localization and the strength of their stimulation, different events might be observed. $\mathrm{IP}_{3}$ Rs can form clusters, where the activation of a single channel (blips) (Parker et al., 1996) can result in $\mathrm{Ca}^{2+}$ induced $\mathrm{Ca}^{2+}$ release by activating the neighboring channels (puffs) (Callamaras et al., 1998; Yao et al., 1995) or in $\mathrm{Ca}^{2+}$ waves propagating trough the cell between the different $\mathrm{IP}_{3} \mathrm{R}$ clusters (Dawson et al., 1999).

Cytosolic $\mathrm{Ca}^{2+}$ rises can promote: i) cell survival and proliferation by modulating gene transcription controlled by the calcineurin/nuclear factor of activated T cells (NFAT) signaling (Crabtree and Schreiber, 2009; Roderick and Cook, 2008), ii) autophagy by activating CAMKK $\beta$ (Woods et al., 2005) or iii) cell death by activating the cell-death executioners caspases and calpains (Blomgren et al., 2001; Harwood et al., 2005; Squier et al., 1994). $\mathrm{Ca}^{2+}$ can also accumulate in different organelles, including mitochondria and lysosomes. In fact, the $\mathrm{ER}$, mitochondria and lysosomes represent $\mathrm{Ca}^{2+-}$ signaling networks through microdomains formed by contact sites (La Rovere et al., 2016; Raffaello et al., 2016). As such, $\mathrm{Ca}^{2+}$ release of the ER leads in a rapid increase in mitochondrial $\mathrm{Ca}^{2+}$ levels, on the one hand dampening cytosolic $\mathrm{Ca}^{2+}$ rises and on the other hand fueling the mitochondria with an essential co-factor for several mitochondrial enzymes involved in the TCA cycle and oxidative phosphorylation (Rizzuto et al., 2012). Yet, $\mathrm{Ca}^{2+}$ overloading in the mitochondria results in loss of mitochondrial membrane integrity, involving the opening of the mitochondrial permeability transition pore either indirectly via ROS produced by disintegration of the complex II (Hwang et al., 2014) or directly by $\mathrm{Ca}^{2+}$ binding to the F0F1-type ATPase dimers, the molecular identity of the pore (Giorgio et al., 2017). Also, lysosomes emerged as important $\mathrm{Ca}^{2+}$-signaling organelles. Lysosomes can sequester $\mathrm{Ca}^{2+}$ released from the ER (Lopez-Sanjurjo et al., 2013), whereas $\mathrm{Ca}^{2+}$ released from lysosomes (and endosomes) can trigger global $\mathrm{Ca}^{2+}$ mobilization from ER $\mathrm{Ca}^{2+}$ stores (Kilpatrick et al., 2016). 
A fraction of the $\mathrm{IP}_{3} \mathrm{R}$ population localizes at the contact sites between the $\mathrm{ER}$ and mitochondria where together with the voltage-dependent anion channels (VDACs) at the outer mitochondrial membrane and the mitochondrial $\mathrm{Ca}^{2+}$ uniporter (MCU) at the inner mitochondrial membrane, facilitate the "quasi-synaptic" ER to mitochondria $\mathrm{Ca}^{2+}$ transfer (Csordas et al., 1999; Raffaello et al., 2016; Rizzuto et al., 1993). Basal $\mathrm{IP}_{3} \mathrm{R}$ activity results in $\mathrm{Ca}^{2+}$ oscillations, which promote mitochondrial functioning and drive NADH and ATP production (Cardenas et al., 2010; Cardenas et al., 2016; Foskett et al., 2007). Inhibition of $\mathrm{IP}_{3} \mathrm{R}$ activity results in decreased $\mathrm{Ca}^{2+}$ supply to the mitochondria, reduced ATP levels and activation of AMPK which triggers autophagy (Cardenas et al., 2010). IP 3 Rs not only sustain cells' mitochondrial bio-energetics but also establish cells' susceptibility to engage apoptosis upon cell damage and cell stress. Furthermore, the action of several cell-death inducing agents, including $\mathrm{H}_{2} \mathrm{O}_{2}$, ceramide and several anti-cancer drugs, is mediated through $\mathrm{Ca}^{2+}$ mobilization from the ER (Bittremieux et al., 2016; Kerkhofs et al., 2017; Marchi et al., 2017a; Parra et al., 2013; Pinton et al., 2001).

\section{$\mathrm{IP}_{\mathbf{3}} \mathbf{R}$ isoforms: structure and regulation}

$\mathrm{IP}_{3} \mathrm{Rs}$ are encoded by three different genes, ITPR1, ITPR2 and ITPR3, resulting in the expression of three isoforms, named $\mathrm{IP}_{3} \mathrm{R} 1, \mathrm{IP}_{3} \mathrm{R} 2$ and $\mathrm{IP}_{3} \mathrm{R} 3$. They share $60-80 \%$ homology in the amino acid sequence. In addition, alternative splicing variants exist, in particular with $\mathrm{IP}_{3} \mathrm{R} 1$ having three splice sites (Foskett; Mikoshiba, 2007). IP 3 R isoforms can assemble into homoor hetero-tetrameric channel complexes and most of the cells express more than one isoform. Nevertheless, very often a particular isoform is predominantly present (Monkawa et al., 1995). This is the case with $I_{3} R 1$ in neuronal cells, $I_{3} R 2$ in liver and muscle cells and $I_{3} R 3$ in most cultured cell types (Ivanova et al., 2014).

$\mathrm{IP}_{3} \mathrm{R} 1, \mathrm{IP}_{3} \mathrm{R} 2$ and $\mathrm{IP}_{3} \mathrm{R} 3$ share similar structure with each monomer consisting of N-terminal ligand-binding domain (LBD), which consists of a suppressor domain (a.a. 1-225 according to the mouse $\mathrm{IP}_{3} \mathrm{R} 1$ sequence) and an $\mathrm{IP}_{3}$-binding core (a.a. 226-604 according to the mouse $\mathrm{IP}_{3} \mathrm{R} 1$ sequence), followed by a central, modulatory domain where multiple regulatory factors bind and regulate the channel activity and finally a C-terminal domain containing 6 trans-membrane segments and a cytosolic tail. The channel pore is formed by the intervening luminal loops located between the $5^{\text {th }}$ and the $6^{\text {th }}$ trans-membrane segments (Baker et al., 2017; Fan et al., 2015; Michikawa et al., 1994; Sudhof et al., 1991; Yoshikawa et al., 1996; Yule et al., 2010). Important structural insights were gained by studying $\mathrm{IP}_{3} \mathrm{R} 1$, the most abundant and thereby the best characterized isoform. Recently, the crystal structure of this isoform in absence of $\mathrm{IP}_{3}$ was determined by a high-resolution cryo-electron microscopy (4.7 $⿱$ A) (Fan et al., 2015; Hamada et al., 2017). This was a critical step in studying the functioning of $\mathrm{IP}_{3} \mathrm{R}$, since it revealed that the cytosolic C-terminus directly interacts with the N-terminal LBD of adjacent subunits (Fan et al., 2015), which interaction is disturbed by conformational change in response to $\mathrm{IP}_{3}$ binding to the LBD. Recently, this model has been refined and it was proposed that the conformational changes that occur upon $\mathrm{IP}_{3}$ binding are transmitted to the channel pore through a unique and distally located in the modulatory domain leaflet structure (Hamada et al., 2017).

Among the key functional regulators of $\mathrm{IP}_{3} \mathrm{Rs}$ are its ligand $\mathrm{IP}_{3}, \mathrm{Ca}^{2+}$ itself, ATP, various proteins as well as different post-translational modifications, including phosphorylation, glycosylation, ubiquitination, thiol-modifications, etc. (Booth et al., 2016; Bultynck et al., 2004; Foskett et al., 2007; Ivanova et al., 2014; Khan et al., 2013; Vanderheyden et al., 2009).

Binding of $\mathrm{IP}_{3}$ to the $\mathrm{IP}_{3}$-binding core is required for channel activation and $\mathrm{IP}_{3}$ Rs deficient for $\mathrm{IP}_{3}$ binding failed to mediate $\mathrm{Ca}^{2+}$ release. The suppressor domain also plays a significant role, since its removal resulted in uncoupling of $\mathrm{IP}_{3}$ binding from channel opening (Uchida et al., 2003). The suppressor domain was proposed to mediate the transfer of the conformational changes, which result from $\mathrm{IP}_{3}$ binding, to the pore opening (Rossi et al., 2009). Furthermore 
the suppressor domain was shown to be part of the region interacting with residues close to the channel pore (Boehning and Joseph, 2000). The three $\mathrm{IP}_{3} \mathrm{R}$ isoforms are characterized by different sensitivity towards $\mathrm{IP}_{3}$ with $\mathrm{IP}_{3} \mathrm{R} 2$ being the most sensitive, followed by $\mathrm{IP}_{3} \mathrm{R} 1$ and finally $\mathrm{IP}_{3} \mathrm{R} 3$ being the least sensitive isoform (Tu et al., 2005b). Additional layer of diversity in the $\mathrm{Ca}^{2+}$ signals is achieved by the formation of $\mathrm{IP}_{3} \mathrm{R}$ heterotetramers. Very recently, by using concatenated $\mathrm{IP}_{3} \mathrm{Rs}$, it was shown that $\mathrm{IP}_{3}$-deficient monomer-subunits acted in a dominantnegative manner over wild-type monomers. In that way the stoichiometry of $\mathrm{IP}_{3}$ binding required for initiation of $\mathrm{Ca}^{2+}$ release was defined and it was demonstrated that all 4 monomers need to be occupied by $\mathrm{IP}_{3}$ in order to achieve proper channel activation (Alzayady et al., 2016; Taylor and Konieczny, 2016). A previous study aimed to examine the contribution of individual isoforms within an $\mathrm{IP}_{3} \mathrm{R}$ heterotetramer toward shaping the $\mathrm{Ca}^{2+}$ signals and it demonstrated that the $\mathrm{IP}_{3}$ sensitivity of $\mathrm{IP}_{3} \mathrm{R}$ heterotetramers is much more complex than a simple sum of the sensitivity of the individual monomers (Chandrasekhar et al., 2016). $\mathrm{IP}_{3} \mathrm{R}$ heterotetramers displayed "blended" sensitivity towards $\mathrm{IP}_{3}$, where the individual monomers contributed equally to the $\mathrm{IP}_{3}$ sensitivity (Alzayady et al., 2013b; Chandrasekhar et al., 2016). Recently, more insights on the spatiotemporal characteristics of initial $\mathrm{Ca}^{2+}$ signals in response to agonists have been obtained, indicating that $\mathrm{Ca}^{2+}$ signals are initiated by immobile $\mathrm{IP}_{3} \mathrm{Rs}$ that are located close to the plasma membrane (Thillaiappan et al., 2017).

Cytosolic $\mathrm{Ca}^{2+}$ was found to exert both, stimulatory and inhibitory effect on $\mathrm{IP}_{3} \mathrm{R}$ function. Such a bell-shaped dependence with low cytosolic $\mathrm{Ca}^{2+}$ levels having stimulatory and high cytosolic $\mathrm{Ca}^{2+}$ levels having inhibitory effect (Bezprozvanny et al., 1991; Finch et al., 1991; Iino, 1990) was described in all three $\mathrm{IP}_{3} \mathrm{R}$ isoforms, but with isoform-specific characteristics (Mak et al., 2001; Miyakawa et al., 1999; Tu et al., 2005a). In contrast to $\mathrm{IP}_{3}$, multiple $\mathrm{Ca}^{2+}$-binding sites were described, some of which appeared conserved among the different isoforms (Sienaert et al., 1996; Sienaert et al., 1997). The exact mechanism and mechanistic role of these sites remains elusive, since different groups described different properties: either inhibition or activation of the receptor upon $\mathrm{Ca}^{2+}$ binding was observed (Mak et al., 1998; Marchant and Taylor, 1997). The ER $\mathrm{Ca}^{2+}$ content also modulates $\mathrm{IP}_{3} \mathrm{R}$ function. Lower ER $\mathrm{Ca}^{2+}$ level results in lower sensitivity of the channel to $\mathrm{IP}_{3}$ (Missiaen et al., 1992; Parys et al., 1993).

Although ATP was not sufficient by itself to activate $\mathrm{IP}_{3} \mathrm{R}$, it displayed stimulatory effect when present in submillimolar concentrations, increasing the frequency of the channel opening triggered by $\mathrm{IP}_{3}$ (Bezprozvanny and Ehrlich, 1993; Missiaen et al., 1997). The binding occur in the modulatory domain of the three different isoforms. In contrast, when present at higher concentrations, ATP inhibited the channel activity (Bezprozvanny and Ehrlich, 1993; Missiaen et al., 1997). The inhibition was proposed to occur due to inhibition of $\mathrm{IP}_{3}$ binding by the high concentrations of ATP (Yule et al., 2010). Similarly to the sensitivity to $\mathrm{IP}_{3}$, the 3 isolated isoforms have different sensitivity to $\mathrm{ATP}$ with $\mathrm{IP}_{3} \mathrm{R} 2$ being again the most sensitive isoform (Betzenhauser et al., 2008). Interestingly, the same isoform is affected by ATP only at submaximal concentration of $\mathrm{IP}_{3}$, while the activity of $\mathrm{IP}_{3} \mathrm{R} 1$ and $\mathrm{IP}_{3} \mathrm{R} 3$ is modulated by ATP in the presence of different concentrations of $\mathrm{IP}_{3}$ (Yule et al., 2010). Furthermore, the mode of ATP regulation appeared to be determined by $\mathrm{IP}_{3} \mathrm{R} 2$ irrespectively of the presence of another isoform (Alzayady et al., 2013b; Chandrasekhar et al., 2016).

\section{$I_{3} R$ ubiquitination and proteasomal degradation}

\section{Ubiquitin-proteasome pathway (UPP)}

Two major pathways for degradation of proteins exist. While autophagy is responsible for the degradation of the long living or aggregated proteins, the UPP is involved in the degradation of the majority of cellular proteins. The proteins that undergo UPP are a subject of a posttranslational modification, during which the 8-kDa ubiquitin molecule is added to the targeted protein. This process might occur as a monoubiquitination at a single or multiple Lys residues 
or as a polyubiquitination, where ubiquitin chains are formed (Dittmar and Selbach, 2017; Komander, 2015). The ubiquitin molecule contains 7 Lys, where the chains can be built (Akutsu et al., 2016). Initially it was proposed that ubiqutination proteins are targeted for degradation by $26 \mathrm{~S}$ proteasome (Hershko and Ciechanover, 1998). By studying the effect of the different chains, it was found that ubiquitination can serve not only as a trigger for proteasomal degradation, but also for other cellular processes, including histone modification, recruitment of proteins involved in DNA damage repair, regulation of protein trafficking (Clague and Urbe, 2010; Komander and Rape, 2012; Kulathu and Komander, 2012; Spence et al., 1995).

\section{$I_{3} R$ down-regulation by ubiquitination}

As stated above, $\mathrm{IP}_{3} \mathrm{R}$ function is regulated by various post-translational modifications, including ubiquitination. Initially, it was observed that over-production of $\mathrm{IP}_{3}$ and thus overstimulation of $\mathrm{IP}_{3} \mathrm{Rs}$ results in a decline in $\mathrm{IP}_{3} \mathrm{R}$-protein levels, (typically about $50 \%$ loss of the total $\mathrm{IP}_{3} \mathrm{R}$ pool) (Wojcikiewicz and Nahorski, 1991). Such an " $\mathrm{IP}_{3} \mathrm{Rs}$ down-regulation" appeared to be a protective mechanism against $G$ protein-coupled receptor activation, which cells employ to avoid chronic $\mathrm{Ca}^{2+}$ mobilization in the cytosol (Wojcikiewicz, 2004). Further studies revealed that the down-regulation of $\mathrm{IP}_{3} \mathrm{Rs}$ is a result of their proteasomal degradation (Wojcikiewicz, 1995; Wojcikiewicz et al., 1994), which is a highly selective process, since other ER proteins were not affected (Pearce et al., 2007; Wang et al., 2009). Further work revealed that (i) $\mathrm{IP}_{3} \mathrm{R}$ degradation occurs in several cell types and models (Oberdorf et al., 1999; Sliter et al., 2011; Wojcikiewicz et al., 1999; Wojcikiewicz et al., 2003) and (ii) all three isoforms serve as substrates for ubiquitination (Oberdorf et al., 1999), although $\mathrm{IP}_{3} \mathrm{R} 2$ appeared to be more resistant to proteasomal degradation (Wojcikiewicz, 1995). The proteasomemediated $\mathrm{IP}_{3} \mathrm{Rs}$ regulation was proposed to occur in response to prolonged exposure of cells to agonists, resulting in sustained $\mathrm{IP}_{3}$ levels, and to require $\mathrm{Ca}^{2+}$ elevations (Alzayady and Wojcikiewicz, 2005; Wojcikiewicz et al., 1994). Interestingly, not all subunits in a tetramer are simultaneously ubiquitinated, allowing fine-tuning through the selective degradation of individual monomers (Sliter et al., 2008). Using $\mathrm{IP}_{3} \mathrm{R} 1$ as a model, it was revealed that potential targets for ubiquitination are at least 11 surface-exposed Lys residues, located in the central, modulatory domain (Sliter et al., 2008). Later it was demonstrated that the other isoforms, $\mathrm{IP}_{3} \mathrm{R} 2$ and $\mathrm{IP}_{3} \mathrm{R} 3$, are also ubiquitinated at approximately the same sites (Sliter et al., 2011). Of note, there is a discrepancy between the ubiquitination of endogenous versus exogenous $\mathrm{IP}_{3} \mathrm{Rs}$. The exogenous $\mathrm{IP}_{3} \mathrm{Rs}$ did not require any stimulus for their ubiquitination and a stimulus-dependent ubiquitination was observed only at very low levels of expression (Wojcikiewicz et al., 2003). Recently, F-box protein FBXL2, one of the four subunits of ubiquitin protein ligase complex called SCFs (SKP1-cullin-F-box), was identified to bind to and ubiquitinate $\mathrm{IP}_{3} \mathrm{R} 3$, thereby targeting it for proteasomal degradation (Bultynck and Campanella, 2017; Kuchay et al., 2017). Such downregulation resulted in a reduced $\mathrm{Ca}^{2+}$ transfer to the mitochondria and to cell resistance to $\mathrm{Ca}^{2+}$-dependent pro-apoptotic stimuli like $\mathrm{H}_{2} \mathrm{O}_{2}$. The interaction between FBXL2 and $\mathrm{IP}_{3} \mathrm{R} 3$ required the $\mathrm{C}$-terminal CaaX domain of FBXL2, which is responsible for FBXL2 membrane localization and a region in the ligand-binding domain of $\operatorname{IP}_{3} \mathrm{R} 3$, more particularly in the $\mathrm{IP}_{3}$-binding core. In agreement with previous studies, the proposed mechanism of $\mathrm{IP}_{3} \mathrm{R} 3$ ubiquitination by FBXL2, involves $\mathrm{IP}_{3}$ binding to the $\mathrm{IP}_{3}$-binding core. This causes conformational changes, displacing the suppressor domain and allowing FBXL2 to reach its binding site (Kuchay et al., 2017).

The ubiquitination of $\mathrm{IP}_{3} \mathrm{R}$ is a complex process, which is regulated by various factors. As stated above, this modification requires $\mathrm{IP}_{3}$ binding to the LBD and occurs in condition of chronic $\mathrm{IP}_{3}$ production. In addition, cytosolic $\mathrm{Ca}^{2+}$ elevations are also needed. Surprisingly, phosphorylation, which was shown to trigger the polyubiquitination of many proteins (Nguyen 
et al., 2013), does not contribute to the modification of $\mathrm{IP}_{3} \mathrm{R}$ (Wojcikiewicz et al., 2003). $\mathrm{IP}_{3} \mathrm{R}$ ubiquitination appeared to be modified in cancer cells as discussed below.

\section{$I_{3} R$ degradation and cancer}

Cancer cells are characterized by uncontrolled proliferation and thereby they often display dysregulated $\mathrm{Ca}^{2+}$ signalling (Monteith et al., 2017). The altered $\mathrm{Ca}^{2+}$ homeostasis results from dysfunction of the main intracellular $\mathrm{Ca}^{2+}$ transport systems due to mutations, aberrant expression, altered stability or regulation (Monteith et al., 2012). As the main intracellular $\mathrm{Ca}^{2+}$ release channel, it is well established that $\mathrm{IP}_{3} \mathrm{R}$ plays a critical role in cancer development and survival (Ivanova et al., 2017). Recently it was demonstrated that cancer cells are addicted to constitutive ER-mitochondria $\mathrm{Ca}^{2+}$ transfer and while in both normal and cancer cells the pharmacological or genetic inhibition of $\mathrm{IP}_{3} \mathrm{R}$ triggers autophagy, only the normal cells take advantage and exploit autophagy as a survival mechanism (Bultynck, 2016; Cardenas et al., 2016). This critical ER-mitochondrial $\mathrm{Ca}^{2+}$ transfer occurs at the contact sites between the two organelles and it is highly dependent on the proper functioning of $\mathrm{IP}_{3} \mathrm{R}$. Many oncogenes and oncosuppressors reside at the MAM interface (Danese et al., 2017; Giorgi et al., 2015; Marchi et al., 2014). These proteins exert precise control of the $\mathrm{Ca}^{2+}$ flux from the ER to the mitochondria either directly by interacting with $\mathrm{IP}_{3} \mathrm{R}$ or indirectly by interacting with other $\mathrm{Ca}^{2+}$-transport systems, thereby affecting steady state ER $\mathrm{Ca}^{2+}$ loading (Akl and Bultynck, 2013; Bittremieux et al., 2016). IP ${ }_{3} \mathrm{R} 3$ is the isoform that is most abundant at the MAMs and as such it is an important target for regulating the $\mathrm{Ca}^{2+}$ release in these microdomains (Bultynck and Campanella, 2017; De Stefani et al., 2012; Marchi et al., 2017b; Pedriali et al., 2017). However, it is clear that $\mathrm{IP}_{3} \mathrm{R}$ function in cells will be influenced also by its stability, which will control the total $\mathrm{Ca}^{2+}$ flux from the ER to the mitochondria and thereby cell death and survival. The $\mathrm{IP}_{3} \mathrm{R}$ stability has recently attracted attention with the identification of different survival proteins as modulators of $\mathrm{IP}_{3} \mathrm{R}$ degradation in cell death and survival with an impact for health and disease.

\section{PTEN and IP 3 R phosphorylation status}

The tumor suppressor PTEN is an evolutionary conserved phosphatase with dual specificity, which is able to remove a phosphate from lipids (Maehama and Dixon, 1998) and proteins (Dey et al., 2008). PTEN contains catalytic and C2 domains and a C-terminal PDZ-binding motif (Waite and Eng, 2002). Its function as a lipid phosphatase is involved in the inhibition of the phosphoinositide 3-kinase/protein kinase B (PKB/Akt) pathway. PTEN dephosphorylates PIP3 to PIP2, preventing PKB/Akt activation (Bos, 1995). Inactivation of PTEN, which is observed in various cancers, including breast, colorectal, prostate cancer, glioblastoma and endometrial carcinoma (Leslie and Downes, 2004), results in increased activity of PKB/Akt promoting cell growth, proliferation and survival (Chalhoub and Baker, 2009). Initially, PTEN was considered to localize exclusively in the cytoplasm and to transiently associate with the plasma membrane, where it dephosphorylates PIP3 (Vazquez et al., 2006). Later studies demonstrated that PTEN can translocate to various organelles including i) nucleus, where it controls DNA reparation and sensitivity to genotoxic stress (Bassi et al., 2013; Trotman et al., 2007), ii) mitochondria where it associates with Bax and promotes apoptotic cell death (Zhu et al., 2006). Recently, PTEN was found to localize at the ER part of the MAMs, where it acts as a protein phosphatase. PTEN co-immunoprecipated with $\mathrm{IP}_{3} \mathrm{R} 3$ and counteracted its phopsphoryation by PKB/Akt. By shifting the phosphorylation state of $\mathrm{IP}_{3} \mathrm{R} 3$ towards desphosphorylation, PTEN promotes $\mathrm{IP}_{3} \mathrm{R} 3$-mediated $\mathrm{Ca}^{2+}$ release from the ER and subsequent $\mathrm{Ca}^{2+}$ flux into mitochondria and cell death (Fig. 1) (Bononi et al., 2013).

\section{PTEN and IP 3 R ubiquitination status}


Recently, a phosphatase-independent role for PTEN has been found in the regulation of $\mathrm{IP}_{3} \mathrm{R}$ activity (Kuchay et al., 2017). In fact, PTEN was reported to compete with FBXL2 for the ligand-binding domain of $\mathrm{IP}_{3} \mathrm{R} 3$, thereby preventing the ubiquitination of the channel. Similarly to FBXL2, PTEN bound more stably to the fragments lacking the suppressor domain. Importantly catalytically-dead PTEN mutants that lack phosphatase activity remained capable of opposing the FBXL2-mediated $\mathrm{IP}_{3} \mathrm{R} 3$ degradation. Given the important role of $\mathrm{IP}_{3} \mathrm{R} 3$ in the regulation of $\mathrm{Ca}^{2+}$ release from the ER and subsequent influx in the mitochondria, the degradation of the channel appears as an important control mechanism of cell death. PTEN loss increased FBXL2 binding to $\mathrm{IP}_{3} \mathrm{R} 3$, thereby promoting $\mathrm{IP}_{3} \mathrm{R} 3$ degradation via FBXL2 and cell resistance towards pro-apoptotic stimuli. Such a mechanism seems to be exploited by cancer cells, which very often display deficiencies in PTEN expression (Fig. 1 \& 2). In human prostate tumors and cancer cell lines the PTEN and IP ${ }_{3} \mathrm{R} 3$ levels correlated. The role of $\mathrm{IP}_{3} \mathrm{R} 3$ degradation is also evident from experiments showing that an $\mathrm{IP}_{3} \mathrm{R} 3$ mutant, which is resistant to degradation, was able to sensitize tumor cells with low or no PTEN expression to $\mathrm{Ca}^{2+}$ dependent cell death (Kuchay et al., 2017).

Hence, ER-resident PTEN has been emerging as a critical regulator of $\mathrm{IP}_{3} \mathrm{R} 3$ function and thereby of $\mathrm{Ca}^{2+}$-dependent cell death. PTEN exploits different mechanisms to reduce proapoptotic ER $\mathrm{Ca}^{2+}$ release and subsequent mitochondrial flux. On one side, PTEN dephosphorylates and suppresses $\mathrm{IP}_{3} \mathrm{R} 3$ (Bononi et al., 2013) and on the other side, it inhibits $\mathrm{IP}_{3} \mathrm{R} 3$ degradation (Kuchay et al., 2017). In both cases, PTEN presence might result in toxic $\mathrm{Ca}^{2+}$ release, while its reduced levels or mutations, which are common for cancer cells, result in reduced $\mathrm{Ca}^{2+}$ release and cell survival.

\section{BAP1 and IP3R ubiquitination status}

BRCA1-associated protein 1 (BAP1) is a potent tumor-suppressor, which is a member of the ubiquitin C-terminal hydrolase subfamily of deubiquitylating enzymes (Carbone et al., 2013). BAP1 mutations and allelic deletions are often observed in human cancers, including mesothelioma, uveal melanoma, intrahepatic cholangiocarcinomas (Jiao et al., 2013), renal cell carcinoma (Farley et al., 2013). BAP1 was described to localize in the nucleus, where it maintains the genome integrity, since cells with reduced BAP1 levels were significantly impaired in DNA repair ( $\mathrm{Yu}$ et al., 2014). Nevertheless, in response to multimonoubiquitylation of its nuclear localization signal, the protein can translocate to the cytosol, although its function there remained largely unknown until recently. Indeed, an ER-resident fraction of BAP1 was demonstrated to exist. Such ER-located BAP1 targets the $\mathrm{IP}_{3} \mathrm{R} 3$, where it deubiqutinates and thereby stabilizes the channel (Bononi et al., 2017). This allowed extensive $\mathrm{Ca}^{2+}$ release upon stimulation, which resulted in cell death. This is particularly relevant for cancer cells displaying reduced levels of BAP1, as evident from the fact that fibroblast cell cultures from different $\mathrm{BAP} 1^{+/-}$carriers appeared to be resistant to apoptosis triggered by various stimuli. In response to toxic agents, $\mathrm{BAP} 1^{+/-}$cells displayed reduced $\mathrm{Ca}^{2+}$ rises in the cytosol and mitochondria compared to normal fibroblasts. This difference was attributed to a difference in the expression of $I_{3} R 3$, since the mRNA levels of $I_{3} R 3$ gene were not affected by the presence of BAP1, while the protein levels were significantly decreased in the absence of BAP1. The binding determinants of the interaction were also investigated and it appeared that BAP1 targets the N-terminus of $\mathrm{IP}_{3} \mathrm{R} 3$ (Fig. 2). The most prominent interaction occurred via the middle domain of BAP1. Although its N-terminal domain was not sufficient by itself to bind to the $\mathrm{N}$-terminus of $\mathrm{IP}_{3} \mathrm{R} 3$, it increased the efficiency of the interaction with the middle domain (Bononi et al., 2017). 
Thus, this study proposes a potential mechanism of cell transformation and apoptosis escape by cancer cells, which includes i) failure in DNA repair due to reduced nuclear BAP1 on one side and ii) decreased $\mathrm{Ca}^{2+}$ release and transfer to the mitochondria due to reduced extra-nuclear BAP1 levels and thereby enhanced $\mathrm{IP}_{3} \mathrm{R} 3$ degradation on another.

\section{$I_{3} R$ and proteolysis}

Proteolysis through specific proteases is another common mechanism for regulation of protein functions. IP ${ }_{3}$ Rs appeared to be substrates of two major classes of proteolytic enzymes, caspases and calpains. Caspases are cysteine aspartic endoproteases, which play the role of apoptotic executioners. Calpains are a class of cysteine proteases, directly activated by intracellular $\mathrm{Ca}^{2+}$, which were also implicated in apoptosis (Momeni, 2011).

\section{Caspase 3-mediated proteolysis of $\mathrm{IP}_{3} \mathrm{R}$ and apoptosis}

Caspase 3 is a major executioner in apoptosis. Multiple proteins were identified as targets of caspase 3, among which critical players in apoptosis, like Bcl-2 family members (Fischer et al., 2003). $I_{3} R 1$, but not $I_{3} R 2$ and $I_{3} R 3$, was found to be a substrate of caspase 3 in cells undergoing apoptosis. It was demonstrated that, during staurosporin (STS) induced apoptosis, caspase 3 targets downstream of the 1888 DEVD consensus site in the central, modulatory domain (domain 4) of $\mathrm{IP}_{3} \mathrm{R} 1$ (Fig. 2) (Hirota et al., 1999). The cleavage results in the generation of two fragments: an $\mathrm{N}$-terminal (containing the $\mathrm{IP}_{3}$ binding site) and an ER associated Cterminal fragment that contains the channel-pore domain. The $\mathrm{C}$-terminal fragment has been proposed to form a Ca ${ }^{2+}-$ leak channel (Assefa et al., 2004; Haug et al., 2000; Hirota et al., 1999; Nakayama et al., 2004; Verbert et al., 2008). Yet, expression of this fragment by itself only mildly increased unidirectional $\mathrm{Ca}^{2+}$-flux from the ER and mildly affected steady-state $\mathrm{ER} \mathrm{Ca}^{2+}$ content, indicating that this fragment by itself cannot deplete the ER. Furthermore, recent work indicated that the $\mathrm{N}$ - and $\mathrm{C}$-terminal fragments that arise upon caspase 3-cleavage remain associated with each other and constitute a functional $\mathrm{IP}_{3} \mathrm{R} 1$ channel that is able to respond to $\mathrm{IP}_{3}$ (Alzayady et al., 2013a). In fact, even recombinant expression of both fragments results in the de novo assembly of a functional $\mathrm{IP}_{3} \mathrm{R} 1$ channel (Alzayady et al., 2013a). Thus, it is clear that caspase 3 mediated cleavage of $\mathrm{IP}_{3} \mathrm{Rs}$ per se is not sufficient to lead to $\mathrm{IP}_{3}$ independent $\mathrm{Ca}^{2+}$ leak from ER. The contribution of caspase 3-mediated $\mathrm{IP}_{3} \mathrm{R} 1$ cleavage to the apoptotic process remains debated. On the one hand, it was shown that triple $\mathrm{IP}_{3} \mathrm{R}$-knockout DT40 cells expressing wild-type $\mathrm{IP}_{3} \mathrm{R} 1$ were susceptible to apoptotic stimuli, while cells expressing a noncleavable $\mathrm{IP}_{3} \mathrm{R}$ mutant displayed slower apoptotic rate and were as resistant to STS as the cells knock out for all $\mathrm{IP}_{3} \mathrm{Rs}$ (Assefa et al., 2004). Also, the $\mathrm{Ca}^{2+}$ rises brought about by STS in $\mathrm{IP}_{3} \mathrm{R} 1$ expressing triple knock out (TKO) cells were annihilated by mutating the caspase 3 -cleavage site in $\mathrm{IP}_{3} \mathrm{R} 1$, resembling the lack of $\mathrm{Ca}^{2+}$ rises observed in the TKO cells. Hence, it was proposed that the pro-apoptotic $\mathrm{Ca}^{2+}$ signals and apoptosis sensitivity/progression are mediated by the cleavage of $\mathrm{IP}_{3} \mathrm{R} 1$ by caspase 3 (Assefa et al., 2004). On the other hand, it was shown that $\mathrm{Ca}^{2+}$ elevations, which occur in the early stages of apoptosis are not necessarily due to $\mathrm{IP}_{3} \mathrm{R}$ cleavage by caspase 3, since inhibition of the enzyme did not affect STS induced $\mathrm{Ca}^{2+}$ rises (Akimzhanov et al.). The cleavage of $\mathrm{IP}_{3} \mathrm{R}$ occurs when cell death is induced by STS and the caspase pool is widely activated while it was not possible to detect the cleaved fragment in cells treated with other apoptotic stimuli like Trail and UV (Elkoreh et al., 2012), suggesting that this event is more likely to happen in the late stage of apoptosis. 
Bok, which is a member of the Bcl-2 family of proteins, can prevent $\mathrm{IP}_{3} \mathrm{R}$ proteolysis during apoptosis (Schulman et al., 2016; Schulman et al., 2013). In contrast to most of the other Bcl-2 proteins, which emerged as regulators of $\mathrm{IP}_{3} \mathrm{R}$ by targeting and directly modulating the channel function (Vervliet et al., 2016), the pro-apoptotic member Bok failed to impact the $\mathrm{IP}_{3} \mathrm{Rs}$ ability to release ER calcium stores (Schulman et al., 2013). Instead, via its N-terminus, Bok binds in the proximity of the caspase 3 binding site (a.a. 1895-1903 of $\mathrm{IP}_{3} \mathrm{R} 1$ ) and thereby antagonizes the proteolysis of the channel (Fig. 2). Bok interacts mainly with $\mathrm{IP}_{3} \mathrm{R} 1$ and $\mathrm{IP}_{3} \mathrm{R} 2$, while $\mathrm{IP}_{3} \mathrm{R} 3$ which hasn't been identified as a target of caspase 3 does not bind prominently to Bok. Bok affects $\mathrm{IP}_{3} \mathrm{R}$ stability and vice versa, $\mathrm{IP}_{3} \mathrm{Rs}$ are actually critical for maintaining Bok stability (Schulman et al., 2016). Recent work indicated that Bok is constitutively active and is not antagonized by anti-apoptotic Bcl-2-family members (Llambi et al., 2016). Thus, its action appears to be controlled at the level of its protein stability, where the majority of Bok is bound to $\mathrm{IP}_{3} \mathrm{Rs}$ and thereby is stabilized and protected from undergoing ER-assocated degradation pathway. Bok remains associated with $\mathrm{IP}_{3} \mathrm{Rs}$ in response to agonists, apoptotic stimuli, ERstress-inducing stimuli, indicating that this mechanism mainly operates to degrade newly synthesized Bok (Schulman et al., 2016). The contribution of $\mathrm{IP}_{3} \mathrm{Rs}$ in this process is not fully understood. On the one hand, $\mathrm{IP}_{3}$ Rs stabilize Bok, thus making Bok available for mitochondrial outer membrane permeabilization (MOMP). On the other hand, $\mathrm{IP}_{3}$ Rs may scaffold Bok and act as an ER sink for Bok, limiting its availability at the mitochondria and preventing its participation in MOMP. Indeed, the pro-apoptotic function of overexpressed Bok was counteracted by its binding to $\mathrm{IP}_{3} \mathrm{R}$ (Schulman et al., 2016).

The role of Bok in human cancer is still under investigation. Although Bok is deleted in different cancer types (Beroukhim et al., 2010), its deletion in mice did not have any significant effect (Ke et al., 2012). Nevertheless, Bok was shown to facilitate apoptosis by promoting MOMP in a Bax/Bak-independent way and that its function is regulated by the regulation of its proteasomal degradation. Thus, it can be speculated that in addition to its role in MOMP, Bok also prevents $\mathrm{IP}_{3} \mathrm{R}$ cleavage and thereby increases the $\mathrm{Ca}^{2+}$ release, supporting an ongoing apoptosis in a $\mathrm{Ca}^{2+}$ dependent manner.

\section{Calpain-mediated proteolysis of $\mathrm{IP}_{3} \mathrm{R}$ and apoptosis}

The other major class of proteases, calpains also target $\mathrm{IP}_{3} \mathrm{Rs}$. Initially, only $\mathrm{IP}_{3} \mathrm{R} 3$ was considered as a substrate (Diaz and Bourguignon, 2000), but later IP $\mathrm{IP}_{3} \mathrm{R} 1$ was also shown to be cleaved by calpains (Kopil et al.). Calpain targeted the modulatory domain of $\mathrm{IP}_{3} \mathrm{R}$, downstream of caspase 3 (Fig. 2) and calpain-mediated degradation of $\mathrm{IP}_{3} \mathrm{R}$ resulted in an accumulation of a stable proteolytic fragment of $\sim 95 \mathrm{kDa}$. Such fragments were able to form channels, which although displayed similar conductance as the wild type $\mathrm{IP}_{3} \mathrm{R}$, had significantly higher open probability at resting $\mathrm{Ca}^{2+}$ and were not activated by $\mathrm{IP}_{3}$ (Kopil et al.). Furthermore, overexpression of this cleaved product led to increased $\mathrm{Ca}^{2+}$ leak and lower ER content, thereby increasing cell death. The authors proposed that the calpain-mediated $\mathrm{IP}_{3} \mathrm{R}$ cleavage is an early event and that the proteolyzed channel may act as a feed-forward mechanism to enhance cell death (Kopil et al.). The same conclusion was made also in another study where calpainmediated cleavage of $\mathrm{IP}_{3} \mathrm{R} 1$ resulted in impaired $\mathrm{ER} \mathrm{Ca}^{2+}$ buffering and thereby in neurodegeneration in primary cortical neurons (Kopil et al., 2012). 


\section{Conclusion}

2 Dysregulated $\mathrm{Ca}^{2+}$ signaling is emerging as an important future of different pathological 3 conditions. The function of $\mathrm{IP}_{3} \mathrm{Rs}$ as a major regulator of intracellular $\mathrm{Ca}^{2+}$ signals and in 4 particular the $\mathrm{IP}_{3} \mathrm{R} 3$ as the main isoform located at the MAMs, is often altered in cancer cells, 5 while $\mathrm{IP}_{3} \mathrm{R} 1$ is mostly affected in neurodegenerative diseases. In addition to the direct 6 modulation of $\mathrm{IP}_{3} \mathrm{Rs}$ by various oncogenes and oncosuppressors, some of them affect also the 7 degradation or the proteolysis of the protein. Major oncosuppressors like PTEN and BAP1 8 facilitate the degradation of $\mathrm{IP}_{3} \mathrm{R} 3$, thereby preventing mitochondrial $\mathrm{Ca}^{2+}$ overload and cell 9 death. In addition, $\mathrm{IP}_{3} \mathrm{R}$ can be subjected to proteolytic cleavage by caspases and calpains, resulting in the generation of fragments with $\mathrm{Ca}^{2+}$ release activity, thereby facilitating ongoing apoptosis.

\section{Acknowledgements}

The work in the authors' laboratory has been supported by grants from the KU Leuven (OT14/101) and from the Research Foundation - Flanders (FWO) (G.0C91.14N, G.0A34.16N, G090118N) and the Research Council - KU Leuven (OT14/101). HI is a holder of a Ph.D. Fellowship from the FWO. 


\section{References}

Akimzhanov, A.M., Barral, J.M., and Boehning, D. Caspase 3 cleavage of the inositol 1,4,5trisphosphate receptor does not contribute to apoptotic calcium release. Cell Calcium. $53,152-158$.

Akl, H., and Bultynck, G. (2013). Altered $\mathrm{Ca}^{2+}$ signaling in cancer cells: proto-oncogenes and tumor suppressors targeting $\mathrm{IP}_{3}$ receptors. Biochim Biophys Acta. 1835, 180-193.

Akutsu, M., Dikic, I., and Bremm, A. (2016). Ubiquitin chain diversity at a glance. J Cell Sci. $129,875-880$.

Alzayady, K.J., Chandrasekhar, R., and Yule, D.I. (2013a). Fragmented inositol 1,4,5trisphosphate receptors retain tetrameric architecture and form functional $\mathrm{Ca}^{2+}$ release channels. J Biol Chem. 288, 11122-11134.

Alzayady, K.J., Wagner, L.E., 2nd, Chandrasekhar, R., Monteagudo, A.M., Godiska, R., Tall, G.G., Joseph, S.K., and Yule, D.I. (2013b). Functional inositol 1,4,5-trisphosphate receptors assembled from concatenated homo- and heteromeric subunits. J Biol Chem.

Alzayady, K.J., Wang, L., Chandrasekhar, R., Wagner, L.E., 2nd, Van Petegem, F., and Yule, D.I. (2016). Defining the stoichiometry of inositol 1,4,5-trisphosphate binding required to initiate $\mathrm{Ca}^{2+}$ release. Sci Signal. 9, ra35.

Alzayady, K.J., and Wojcikiewicz, R.J. (2005). The role of $\mathrm{Ca}^{2+}$ in triggering inositol 1,4,5trisphosphate receptor ubiquitination. Biochem J. 392, 601-606.

Assefa, Z., Bultynck, G., Szlufcik, K., Nadif Kasri, N., Vermassen, E., Goris, J., Missiaen, L., Callewaert, G., Parys, J.B., and De Smedt, H. (2004). Caspase-3-induced truncation of type 1 inositol trisphosphate receptor accelerates apoptotic cell death and induces inositol trisphosphate-independent calcium release during apoptosis. J Biol Chem. 279, 43227-43236.

Baker, M.R., Fan, G., and Serysheva, II. (2017). Structure of IP3R channel: high-resolution insights from cryo-EM. Curr Opin Struct Biol. 46, 38-47.

Bassi, C., Ho, J., Srikumar, T., Dowling, R.J., Gorrini, C., Miller, S.J., Mak, T.W., Neel, B.G., Raught, B., and Stambolic, V. (2013). Nuclear PTEN controls DNA repair and sensitivity to genotoxic stress. Science. 341, 395-399.

Beroukhim, R., Mermel, C.H., Porter, D., Wei, G., Raychaudhuri, S., Donovan, J., Barretina, J., Boehm, J.S., Dobson, J., Urashima, M., Mc Henry, K.T., Pinchback, R.M., Ligon, A.H., Cho, Y.J., Haery, L., Greulich, H., Reich, M., Winckler, W., Lawrence, M.S., Weir, B.A., Tanaka, K.E., Chiang, D.Y., Bass, A.J., Loo, A., Hoffman, C., Prensner, J., Liefeld, T., Gao, Q., Yecies, D., Signoretti, S., Maher, E., Kaye, F.J., Sasaki, H., Tepper, J.E., Fletcher, J.A., Tabernero, J., Baselga, J., Tsao, M.S., Demichelis, F., Rubin, M.A., Janne, P.A., Daly, M.J., Nucera, C., Levine, R.L., Ebert, B.L., Gabriel, S., Rustgi, A.K., Antonescu, C.R., Ladanyi, M., Letai, A., Garraway, L.A., Loda, M., Beer, D.G., True, L.D., Okamoto, A., Pomeroy, S.L., Singer, S., Golub, T.R., Lander, E.S., Getz, G., Sellers, W.R., and Meyerson, M. (2010). The landscape of somatic copy-number alteration across human cancers. Nature. 463, 899-905.

Berridge, M.J. (2007). Inositol trisphosphate and calcium oscillations. Biochem Soc Symp, 1-7.

Berridge, M.J., Bootman, M.D., and Roderick, H.L. (2003). Calcium signalling: dynamics, homeostasis and remodelling. Nat Rev Mol Cell Biol. 4, 517-529.

Berridge, M.J., Lipp, P., and Bootman, M.D. (2000). The versatility and universality of calcium signalling. Nat Rev Mol Cell Biol. 1, 11-21.

Betzenhauser, M.J., Wagner, L.E., 2nd, Iwai, M., Michikawa, T., Mikoshiba, K., and Yule, D.I. (2008). ATP modulation of $\mathrm{Ca}^{2+}$ release by type- 2 and type-3 inositol $(1,4,5)$ triphosphate receptors. Differing ATP sensitivities and molecular determinants of action. J Biol Chem. 283, 21579-21587. 
Bezprozvanny, I., and Ehrlich, B.E. (1993). ATP modulates the function of inositol 1,4,5trisphosphate-gated channels at two sites. Neuron. 10, 1175-1184.

Bezprozvanny, I., Watras, J., and Ehrlich, B.E. (1991). Bell-shaped calcium-response curves of Ins $(1,4,5) \mathrm{P} 3$ - and calcium-gated channels from endoplasmic reticulum of cerebellum. Nature. 351, 751-754.

Bittremieux, M., Parys, J.B., Pinton, P., and Bultynck, G. (2016). ER functions of oncogenes and tumor suppressors: Modulators of intracellular $\mathrm{Ca}^{2+}$ signaling. Biochim Biophys Acta. 1863, 1364-1378.

Blomgren, K., Zhu, C., Wang, X., Karlsson, J.O., Leverin, A.L., Bahr, B.A., Mallard, C., and Hagberg, H. (2001). Synergistic activation of caspase-3 by m-calpain after neonatal hypoxia-ischemia: a mechanism of "pathological apoptosis"? J Biol Chem. 276, 1019110198.

Boehning, D., and Joseph, S.K. (2000). Direct association of ligand-binding and pore domains in homo- and heterotetrameric inositol 1,4,5-trisphosphate receptors. EMBO J. 19, 5450-5459.

Bononi, A., Bonora, M., Marchi, S., Missiroli, S., Poletti, F., Giorgi, C., Pandolfi, P.P., and Pinton, P. (2013). Identification of PTEN at the ER and MAMs and its regulation of Ca signaling and apoptosis in a protein phosphatase-dependent manner. Cell Death Differ.

Bononi, A., Giorgi, C., Patergnani, S., Larson, D., Verbruggen, K., Tanji, M., Pellegrini, L., Signorato, V., Olivetto, F., Pastorino, S., Nasu, M., Napolitano, A., Gaudino, G., Morris, P., Sakamoto, G., Ferris, L.K., Danese, A., Raimondi, A., Tacchetti, C., Kuchay, S., Pass, H.I., Affar, E.B., Yang, H., Pinton, P., and Carbone, M. (2017). BAP1 regulates IP3R3-mediated $\mathrm{Ca}^{2+}$ flux to mitochondria suppressing cell transformation. Nature. 546, 549-553.

Booth, D.M., Enyedi, B., Geiszt, M., Varnai, P., and Hajnoczky, G. (2016). Redox Nanodomains Are Induced by and Control Calcium Signaling at the ER-Mitochondrial Interface. Molecular cell. 63, 240-248.

Bos, J.L. (1995). A target for phosphoinositide 3-kinase: Akt/PKB. Trends Biochem Sci. 20, 441-442.

Bultynck, G. (2016). Onco-IP3Rs Feed Cancerous Cravings for Mitochondrial $\mathrm{Ca}^{2+}$. Trends Biochem Sci. 41, 390-393.

Bultynck, G., and Campanella, M. (2017). Tumor suppressive $\mathrm{Ca}^{2+}$ signaling is driven by $\mathrm{IP}_{3}$ receptor fitness. Cell Stress. 1, 73-78.

Bultynck, G., Szlufcik, K., Kasri, N.N., Assefa, Z., Callewaert, G., Missiaen, L., Parys, J.B., and De Smedt, H. (2004). Thimerosal stimulates $\mathrm{Ca}^{2+}$ flux through inositol 1,4,5trisphosphate receptor type 1 , but not type 3 , via modulation of an isoform-specific $\mathrm{Ca}^{2+}$-dependent intramolecular interaction. Biochem J. 381, 87-96.

Callamaras, N., Marchant, J.S., Sun, X.P., and Parker, I. (1998). Activation and co-ordination of InsP3-mediated elementary $\mathrm{Ca}^{2+}$ events during global $\mathrm{Ca}^{2+}$ signals in Xenopus oocytes. J Physiol. 509 ( Pt 1), 81-91.

Carbone, M., Yang, H., Pass, H.I., Krausz, T., Testa, J.R., and Gaudino, G. (2013). BAP1 and cancer. Nat Rev Cancer. 13, 153-159.

Cardenas, C., Miller, R.A., Smith, I., Bui, T., Molgo, J., Muller, M., Vais, H., Cheung, K.H., Yang, J., Parker, I., Thompson, C.B., Birnbaum, M.J., Hallows, K.R., and Foskett, J.K. (2010). Essential regulation of cell bioenergetics by constitutive InsP3 receptor $\mathrm{Ca}^{2+}$ transfer to mitochondria. Cell. 142, 270-283.

Cardenas, C., Muller, M., McNeal, A., Lovy, A., Jana, F., Bustos, G., Urra, F., Smith, N., Molgo, J., Diehl, J.A., Ridky, T.W., and Foskett, J.K. (2016). Selective Vulnerability of Cancer Cells by Inhibition of $\mathrm{Ca}^{2+}$ Transfer from Endoplasmic Reticulum to Mitochondria. Cell Rep. 15, 219-220. 
Chalhoub, N., and Baker, S.J. (2009). PTEN and the PI3-kinase pathway in cancer. Annu Rev Pathol. 4, 127-150.

Chandrasekhar, R., Alzayady, K.J., Wagner, L.E., 2nd, and Yule, D.I. (2016). Unique Regulatory Properties of Heterotetrameric Inositol 1,4,5-Trisphosphate Receptors Revealed by Studying Concatenated Receptor Constructs. J Biol Chem. 291, 48464860.

Clague, M.J., and Urbe, S. (2010). Ubiquitin: same molecule, different degradation pathways. Cell. 143, 682-685.

Clapham, D.E. (2007). Calcium signaling. Cell. 131, 1047-1058.

Crabtree, G.R., and Schreiber, S.L. (2009). SnapShot: $\mathrm{Ca}^{2+}$-calcineurin-NFAT signaling. Cell. $138,210,210$ e211.

Csordas, G., Thomas, A.P., and Hajnoczky, G. (1999). Quasi-synaptic calcium signal transmission between endoplasmic reticulum and mitochondria. EMBO J. 18, 96-108.

Danese, A., Patergnani, S., Bonora, M., Wieckowski, M.R., Previati, M., Giorgi, C., and Pinton, P. (2017). Calcium regulates cell death in cancer: Roles of the mitochondria and mitochondria-associated membranes (MAMs). Biochim Biophys Acta. 1858, 615-627.

Dawson, S.P., Keizer, J., and Pearson, J.E. (1999). Fire-diffuse-fire model of dynamics of intracellular calcium waves. Proc Natl Acad Sci U S A. 96, 6060-6063.

De Stefani, D., Bononi, A., Romagnoli, A., Messina, A., De Pinto, V., Pinton, P., and Rizzuto, R. (2012). VDAC1 selectively transfers apoptotic $\mathrm{Ca}^{2+}$ signals to mitochondria. Cell Death Differ. 19, 267-273.

Dey, N., Crosswell, H.E., De, P., Parsons, R., Peng, Q., Su, J.D., and Durden, D.L. (2008). The protein phosphatase activity of PTEN regulates SRC family kinases and controls glioma migration. Cancer Res. 68, 1862-1871.

Diaz, F., and Bourguignon, L.Y. (2000). Selective down-regulation of $\mathrm{IP}_{3}$ receptor subtypes by caspases and calpain during TNF alpha -induced apoptosis of human T-lymphoma cells. Cell Calcium. 27, 315-328.

Dittmar, G., and Selbach, M. (2017). Deciphering the Ubiquitin Code. Molecular cell. 65, 779780.

Elkoreh, G., Blais, V., Beliveau, E., Guillemette, G., and Denault, J.B. (2012). Type 1 inositol1,4,5-trisphosphate receptor is a late substrate of caspases during apoptosis. $J$ Cell Biochem. 113, 2775-2784.

Fan, G., Baker, M.L., Wang, Z., Baker, M.R., Sinyagovskiy, P.A., Chiu, W., Ludtke, S.J., and Serysheva, II. (2015). Gating machinery of InsP3R channels revealed by electron cryomicroscopy. Nature. 527, 336-341.

Farley, M.N., Schmidt, L.S., Mester, J.L., Pena-Llopis, S., Pavia-Jimenez, A., Christie, A., Vocke, C.D., Ricketts, C.J., Peterson, J., Middelton, L., Kinch, L., Grishin, N., Merino, M.J., Metwalli, A.R., Xing, C., Xie, X.J., Dahia, P.L.M., Eng, C., Linehan, W.M., and Brugarolas, J. (2013). A novel germline mutation in BAP1 predisposes to familial clearcell renal cell carcinoma. Mol Cancer Res. 11, 1061-1071.

Fedorenko, O.A., Popugaeva, E., Enomoto, M., Stathopulos, P.B., Ikura, M., and Bezprozvanny, I. (2014). Intracellular calcium channels: inositol-1,4,5-trisphosphate receptors. Eur J Pharmacol. 739, 39-48.

Finch, E.A., Turner, T.J., and Goldin, S.M. (1991). Calcium as a coagonist of inositol 1,4,5trisphosphate-induced calcium release. Science. 252, 443-446.

Fischer, U., Janicke, R.U., and Schulze-Osthoff, K. (2003). Many cuts to ruin: a comprehensive update of caspase substrates. Cell Death Differ. 10, 76-100.

Foskett, J.K. Inositol trisphosphate receptor $\mathrm{Ca}^{2+}$ release channels in neurological diseases. Pflugers Arch. 460, 481-494. 
Foskett, J.K., White, C., Cheung, K.H., and Mak, D.O. (2007). Inositol trisphosphate receptor $\mathrm{Ca}^{2+}$ release channels. Physiol Rev. 87, 593-658.

Giorgi, C., Missiroli, S., Patergnani, S., Duszynski, J., Wieckowski, M.R., and Pinton, P. (2015). Mitochondria-associated membranes: composition, molecular mechanisms, and physiopathological implications. Antioxid Redox Signal. 22, 995-1019.

Giorgio, V., Burchell, V., Schiavone, M., Bassot, C., Minervini, G., Petronilli, V., Argenton, F., Forte, M., Tosatto, S., Lippe, G., and Bernardi, P. (2017). $\mathrm{Ca}^{2+}$ binding to F-ATP synthase beta subunit triggers the mitochondrial permeability transition. EMBO Rep. $18,1065-1076$.

Hamada, K., Miyatake, H., Terauchi, A., and Mikoshiba, K. (2017). IP 3 -mediated gating mechanism of the $\mathrm{IP}_{3}$ receptor revealed by mutagenesis and X-ray crystallography. Proc Natl Acad Sci U S A. 114, 4661-4666.

Harwood, S.M., Yaqoob, M.M., and Allen, D.A. (2005). Caspase and calpain function in cell death: bridging the gap between apoptosis and necrosis. Ann Clin Biochem. 42, 415431.

Haug, L.S., Walaas, S.I., and Ostvold, A.C. (2000). Degradation of the type I inositol 1,4,5trisphosphate receptor by caspase-3 in SH-SY5Y neuroblastoma cells undergoing apoptosis. J Neurochem. 75, 1852-1861.

Hershko, A., and Ciechanover, A. (1998). The ubiquitin system. Annu Rev Biochem. 67, 425479.

Hirota, J., Furuichi, T., and Mikoshiba, K. (1999). Inositol 1,4,5-trisphosphate receptor type 1 is a substrate for caspase- 3 and is cleaved during apoptosis in a caspase-3-dependent manner. J Biol Chem. 274, 34433-34437.

Hwang, M.S., Schwall, C.T., Pazarentzos, E., Datler, C., Alder, N.N., and Grimm, S. (2014). Mitochondrial $\mathrm{Ca}^{2+}$ influx targets cardiolipin to disintegrate respiratory chain complex II for cell death induction. Cell Death Differ. 21, 1733-1745.

Iino, M. (1990). Biphasic $\mathrm{Ca}^{2+}$ dependence of inositol 1,4,5-trisphosphate-induced Ca release in smooth muscle cells of the guinea pig taenia caeci. J Gen Physiol. 95, 1103-1122.

Ivanova, H., Kerkhofs, M., La Rovere, R.M., and Bultynck, G. (2017). Endoplasmic ReticulumMitochondrial $\mathrm{Ca}^{2+}$ Fluxes Underlying Cancer Cell Survival. Front Oncol. 7, 70.

Ivanova, H., Vervliet, T., Missiaen, L., Parys, J.B., De Smedt, H., and Bultynck, G. (2014). Inositol 1,4,5-trisphosphate receptor-isoform diversity in cell death and survival. Biochim Biophys Acta. 1843, 2164-2183.

Jiao, Y., Pawlik, T.M., Anders, R.A., Selaru, F.M., Streppel, M.M., Lucas, D.J., Niknafs, N., Guthrie, V.B., Maitra, A., Argani, P., Offerhaus, G.J.A., Roa, J.C., Roberts, L.R., Gores, G.J., Popescu, I., Alexandrescu, S.T., Dima, S., Fassan, M., Simbolo, M., Mafficini, A., Capelli, P., Lawlor, R.T., Ruzzenente, A., Guglielmi, A., Tortora, G., de Braud, F., Scarpa, A., Jarnagin, W., Klimstra, D., Karchin, R., Velculescu, V.E., Hruban, R.H., Vogelstein, B., Kinzler, K.W., Papadopoulos, N., and Wood, L.D. (2013). Exome sequencing identifies frequent inactivating mutations in BAP1, ARID1A and PBRM1 in intrahepatic cholangiocarcinomas. Nat Genet. 45, 1470-1473.

Ke, F., Voss, A., Kerr, J.B., O'Reilly, L.A., Tai, L., Echeverry, N., Bouillet, P., Strasser, A., and Kaufmann, T. (2012). BCL-2 family member BOK is widely expressed but its loss has only minimal impact in mice. Cell Death Differ. 19, 915-925.

Kerkhofs, M., Giorgi, C., Marchi, S., Seitaj, B., Parys, J.B., Pinton, P., Bultynck, G., and Bittremieux, M. (2017). Alterations in $\mathrm{Ca}^{2+}$ Signalling via ER-Mitochondria Contact Site Remodelling in Cancer. Adv Exp Med Biol. 997, 225-254.

Khan, S.A., Rossi, A.M., Riley, A.M., Potter, B.V., and Taylor, C.W. (2013). Subtype-selective regulation of IP(3) receptors by thimerosal via cysteine residues within the IP(3)binding core and suppressor domain. Biochem J. 451, 177-184. 
Kilpatrick, B.S., Yates, E., Grimm, C., Schapira, A.H., and Patel, S. (2016). Endo-lysosomal TRP mucolipin-1 channels trigger global ER $\mathrm{Ca}^{2+}$ release and $\mathrm{Ca}^{2+}$ influx. J Cell Sci. 129, 3859-3867.

Komander, D. (2015). Biochemistry. Details of destruction, one molecule at a time. Science. 348, 183-184.

Komander, D., and Rape, M. (2012). The ubiquitin code. Annu Rev Biochem. 81, 203-229.

Kopil, C.M., Siebert, A.P., Foskett, J.K., and Neumar, R.W. (2012). Calpain-cleaved type 1 inositol 1,4,5-trisphosphate receptor impairs ER $\mathrm{Ca}^{2+}$ buffering and causes neurodegeneration in primary cortical neurons. J Neurochem. 123, 147-158.

Kopil, C.M., Vais, H., Cheung, K.H., Siebert, A.P., Mak, D.O., Foskett, J.K., and Neumar, R.W. Calpain-cleaved type 1 inositol 1,4,5-trisphosphate receptor $\left(\operatorname{InsP}_{3} R 1\right)$ has $\operatorname{InsP}_{3}-$ independent gating and disrupts intracellular $\mathrm{Ca}^{2+}$ homeostasis. J Biol Chem. 286, 35998-36010.

Kuchay, S., Giorgi, C., Simoneschi, D., Pagan, J., Missiroli, S., Saraf, A., Florens, L., Washburn, M.P., Collazo-Lorduy, A., Castillo-Martin, M., Cordon-Cardo, C., Sebti, S.M., Pinton, P., and Pagano, M. (2017). PTEN counteracts FBXL2 to promote IP3R3and $\mathrm{Ca}^{2+}$-mediated apoptosis limiting tumour growth. Nature. 546, 554-558.

Kulathu, Y., and Komander, D. (2012). Atypical ubiquitylation - the unexplored world of polyubiquitin beyond Lys48 and Lys63 linkages. Nat Rev Mol Cell Biol. 13, 508-523.

La Rovere, R.M., Roest, G., Bultynck, G., and Parys, J.B. (2016). Intracellular $\mathrm{Ca}^{2+}$ signaling and $\mathrm{Ca}^{2+}$ microdomains in the control of cell survival, apoptosis and autophagy. Cell Calcium. 60, 74-87.

Leslie, N.R., and Downes, C.P. (2004). PTEN function: how normal cells control it and tumour cells lose it. Biochem J. 382, 1-11.

Llambi, F., Wang, Y.M., Victor, B., Yang, M., Schneider, D.M., Gingras, S., Parsons, M.J., Zheng, J.H., Brown, S.A., Pelletier, S., Moldoveanu, T., Chen, T., and Green, D.R. (2016). BOK Is a Non-canonical BCL-2 Family Effector of Apoptosis Regulated by ER-Associated Degradation. Cell. 165, 421-433.

Lopez-Sanjurjo, C.I., Tovey, S.C., Prole, D.L., and Taylor, C.W. (2013). Lysosomes shape Ins(1,4,5) $\mathrm{P}_{3}$-evoked $\mathrm{Ca}^{2+}$ signals by selectively sequestering $\mathrm{Ca}^{2+}$ released from the endoplasmic reticulum. J Cell Sci. 126, 289-300.

Maehama, T., and Dixon, J.E. (1998). The tumor suppressor, PTEN/MMAC1, dephosphorylates the lipid second messenger, phosphatidylinositol 3,4,5-trisphosphate. J Biol Chem. 273, 13375-13378.

Mak, D.O., McBride, S., and Foskett, J.K. (1998). Inositol 1,4,5-trisphosphate [correction of tris-phosphate] activation of inositol trisphosphate [correction of tris-phosphate] receptor $\mathrm{Ca}^{2+}$ channel by ligand tuning of $\mathrm{Ca}^{2+}$ inhibition. Proc Natl Acad Sci U S A. 95, 15821-15825.

Mak, D.O., McBride, S., and Foskett, J.K. (2001). Regulation by $\mathrm{Ca}^{2+}$ and inositol 1,4,5trisphosphate (InsP3) of single recombinant type $3 \mathrm{InsP}_{3}$ receptor channels. $\mathrm{Ca}^{2+}$ activation uniquely distinguishes types 1 and $3 \mathrm{InsP}_{3}$ receptors. J Gen Physiol. 117, 435446.

Marchant, J.S., and Taylor, C.W. (1997). Cooperative activation of IP3 receptors by sequential binding of $\mathrm{IP}_{3}$ and $\mathrm{Ca}^{2+}$ safeguards against spontaneous activity. Curr Biol. 7, 510-518.

Marchi, S., Bittremieux, M., Missiroli, S., Morganti, C., Patergnani, S., Sbano, L., Rimessi, A., Kerkhofs, M., Parys, J.B., Bultynck, G., Giorgi, C., and Pinton, P. (2017a). Endoplasmic Reticulum-Mitochondria Communication Through $\mathrm{Ca}^{2+}$ Signaling: The Importance of Mitochondria-Associated Membranes (MAMs). Adv Exp Med Biol. 997, 49-67. 
Marchi, S., Giorgi, C., Oparka, M., Duszynski, J., Wieckowski, M.R., and Pinton, P. (2014). Oncogenic and oncosuppressive signal transduction at mitochondria-associated endoplasmic reticulum membranes. Mol Cell Oncol. 1, e956469.

Marchi, S., Patergnani, S., Missiroli, S., Morciano, G., Rimessi, A., Wieckowski, M.R., Giorgi, C., and Pinton, P. (2017b). Mitochondrial and endoplasmic reticulum calcium homeostasis and cell death. Cell Calcium.

Michikawa, T., Hamanaka, H., Otsu, H., Yamamoto, A., Miyawaki, A., Furuichi, T., Tashiro, Y., and Mikoshiba, K. (1994). Transmembrane topology and sites of N-glycosylation of inositol 1,4,5-trisphosphate receptor. J Biol Chem. 269, 9184-9189.

Mikoshiba, K. (2007). The $\mathrm{IP}_{3}$ receptor/Ca ${ }^{2+}$ channel and its cellular function. Biochem Soc Symp, 9-22.

Mikoshiba, K. (2015). Role of $\mathrm{IP}_{3}$ receptor signaling in cell functions and diseases. Adv Biol Regul. 57, 217-227.

Missiaen, L., De Smedt, H., Droogmans, G., and Casteels, R. (1992). Luminal Ca ${ }^{2+}$ controls the activation of the inositol 1,4,5-trisphosphate receptor by cytosolic $\mathrm{Ca}^{2+} . \mathrm{J}$ Biol Chem. 267, 22961-22966.

Missiaen, L., Parys, J.B., Smedt, H.D., Sienaert, I., Sipma, H., Vanlingen, S., Maes, K., and Casteels, R. (1997). Effect of adenine nucleotides on myo-inositol-1,4,5-trisphosphateinduced calcium release. Biochem J. 325 ( Pt 3), 661-666.

Miyakawa, T., Maeda, A., Yamazawa, T., Hirose, K., Kurosaki, T., and Iino, M. (1999). Encoding of $\mathrm{Ca}^{2+}$ signals by differential expression of IP3 receptor subtypes. Embo $J$. $18,1303-1308$.

Momeni, H.R. (2011). Role of calpain in apoptosis. Cell J. 13, 65-72.

Monkawa, T., Miyawaki, A., Sugiyama, T., Yoneshima, H., Yamamoto-Hino, M., Furuichi, T., Saruta, T., Hasegawa, M., and Mikoshiba, K. (1995). Heterotetrameric complex formation of inositol 1,4,5-trisphosphate receptor subunits. J Biol Chem. 270, 1470014704.

Monteith, G.R., Davis, F.M., and Roberts-Thomson, S.J. (2012). Calcium channels and pumps in cancer: changes and consequences. J Biol Chem. 287, 31666-31673.

Monteith, G.R., Prevarskaya, N., and Roberts-Thomson, S.J. (2017). The calcium-cancer signalling nexus. Nat Rev Cancer. 17, 367-380.

Nakayama, T., Hattori, M., Uchida, K., Nakamura, T., Tateishi, Y., Bannai, H., Iwai, M., Michikawa, T., Inoue, T., and Mikoshiba, K. (2004). The regulatory domain of the inositol 1,4,5-trisphosphate receptor is necessary to keep the channel domain closed: possible physiological significance of specific cleavage by caspase 3. Biochem J. 377, 299-307.

Nguyen, L.K., Kolch, W., and Kholodenko, B.N. (2013). When ubiquitination meets phosphorylation: a systems biology perspective of EGFR/MAPK signalling. Cell Commun Signal. 11, 52.

Oberdorf, J., Webster, J.M., Zhu, C.C., Luo, S.G., and Wojcikiewicz, R.J. (1999). Downregulation of types I, II and III inositol 1,4,5-trisphosphate receptors is mediated by the ubiquitin/proteasome pathway. Biochem J. 339 ( Pt 2), 453-461.

Parker, I., Choi, J., and Yao, Y. (1996). Elementary events of InsP3-induced Ca ${ }^{2+}$ liberation in Xenopus oocytes: hot spots, puffs and blips. Cell Calcium. 20, 105-121.

Parra, V., Moraga, F., Kuzmicic, J., Lopez-Crisosto, C., Troncoso, R., Torrealba, N., Criollo, A., Diaz-Elizondo, J., Rothermel, B.A., Quest, A.F., and Lavandero, S. (2013). Calcium and mitochondrial metabolism in ceramide-induced cardiomyocyte death. Biochim Biophys Acta. 1832, 1334-1344.

Parys, J.B., Missiaen, L., De Smedt, H., and Casteels, R. (1993). Loading dependence of inositol 1,4,5-trisphosphate-induced $\mathrm{Ca}^{2+}$ release in the clonal cell line $\mathrm{A} 7 \mathrm{r} 5$. 
Implications for the mechanism of quantal $\mathrm{Ca}^{2+}$ release. J Biol Chem. 268, 2520625212.

Pearce, M.M., Wang, Y., Kelley, G.G., and Wojcikiewicz, R.J. (2007). SPFH2 mediates the endoplasmic reticulum-associated degradation of inositol 1,4,5-trisphosphate receptors and other substrates in mammalian cells. J Biol Chem. 282, 20104-20115.

Pedriali, G., Rimessi, A., Sbano, L., Giorgi, C., Wieckowski, M.R., Previati, M., and Pinton, P. (2017). Regulation of Endoplasmic Reticulum-Mitochondria $\mathrm{Ca}^{2+}$ Transfer and Its Importance for Anti-Cancer Therapies. Front Oncol. 7, 180.

Pinton, P., Ferrari, D., Rapizzi, E., Di Virgilio, F., Pozzan, T., and Rizzuto, R. (2001). The Ca ${ }^{2+}$ concentration of the endoplasmic reticulum is a key determinant of ceramide-induced apoptosis: significance for the molecular mechanism of Bcl-2 action. EMBO J. 20, 2690-2701.

Prins, D., and Michalak, M. (2011). Organellar calcium buffers. Cold Spring Harb Perspect Biol. 3.

Raffaello, A., Mammucari, C., Gherardi, G., and Rizzuto, R. (2016). Calcium at the Center of Cell Signaling: Interplay between Endoplasmic Reticulum, Mitochondria, and Lysosomes. Trends Biochem Sci. 41, 1035-1049.

Rizzuto, R., Brini, M., Murgia, M., and Pozzan, T. (1993). Microdomains with high $\mathrm{Ca}^{2+}$ close to IP3-sensitive channels that are sensed by neighboring mitochondria. Science. 262, 744-747.

Rizzuto, R., De Stefani, D., Raffaello, A., and Mammucari, C. (2012). Mitochondria as sensors and regulators of calcium signalling. Nat Rev Mol Cell Biol. 13, 566-578.

Roderick, H.L., and Cook, S.J. (2008). $\mathrm{Ca}^{2+}$ signalling checkpoints in cancer: remodelling $\mathrm{Ca}^{2+}$ for cancer cell proliferation and survival. Nat Rev Cancer. 8, 361-375.

Rossi, A.M., Riley, A.M., Tovey, S.C., Rahman, T., Dellis, O., Taylor, E.J., Veresov, V.G., Potter, B.V., and Taylor, C.W. (2009). Synthetic partial agonists reveal key steps in $\mathrm{IP}_{3}$ receptor activation. Nat Chem Biol. 5, 631-639.

Schulman, J.J., Wright, F.A., Han, X., Zluhan, E.J., Szczesniak, L.M., and Wojcikiewicz, R.J. (2016). The Stability and Expression Level of Bok Are Governed by Binding to Inositol 1,4,5-Trisphosphate Receptors. J Biol Chem. 291, 11820-11828.

Schulman, J.J., Wright, F.A., Kaufmann, T., and Wojcikiewicz, R.J. (2013). The Bcl-2 protein family member Bok binds to the coupling domain of inositol 1,4,5-trisphosphate receptors and protects them from proteolytic cleavage. J Biol Chem. 288, 25340-25349.

Sienaert, I., De Smedt, H., Parys, J.B., Missiaen, L., Vanlingen, S., Sipma, H., and Casteels, R. (1996). Characterization of a cytosolic and a luminal $\mathrm{Ca}^{2+}$ binding site in the type I inositol 1,4,5-trisphosphate receptor. J Biol Chem. 271, 27005-27012.

Sienaert, I., Missiaen, L., De Smedt, H., Parys, J.B., Sipma, H., and Casteels, R. (1997). Molecular and functional evidence for multiple $\mathrm{Ca}^{2+}$-binding domains in the type 1 inositol 1,4,5-trisphosphate receptor. J Biol Chem. 272, 25899-25906.

Sliter, D.A., Aguiar, M., Gygi, S.P., and Wojcikiewicz, R.J. (2011). Activated inositol 1,4,5trisphosphate receptors are modified by homogeneous Lys-48- and Lys-63-linked ubiquitin chains, but only Lys-48-linked chains are required for degradation. $J$ Biol Chem. 286, 1074-1082.

Sliter, D.A., Kubota, K., Kirkpatrick, D.S., Alzayady, K.J., Gygi, S.P., and Wojcikiewicz, R.J. (2008). Mass spectrometric analysis of type 1 inositol 1,4,5-trisphosphate receptor ubiquitination. J Biol Chem. 283, 35319-35328.

Spence, J., Sadis, S., Haas, A.L., and Finley, D. (1995). A ubiquitin mutant with specific defects in DNA repair and multiubiquitination. Mol Cell Biol. 15, 1265-1273.

Squier, M.K., Miller, A.C., Malkinson, A.M., and Cohen, J.J. (1994). Calpain activation in apoptosis. J Cell Physiol. 159, 229-237. 
Sudhof, T.C., Newton, C.L., Archer, B.T., 3rd, Ushkaryov, Y.A., and Mignery, G.A. (1991). Structure of a novel InsP3 receptor. Embo J. 10, 3199-3206.

Taylor, C.W., Genazzani, A.A., and Morris, S.A. (1999). Expression of inositol trisphosphate receptors. Cell Calcium. 26, 237-251.

Taylor, C.W., and Konieczny, V. (2016). IP 3 receptors: Take four $\mathrm{IP}_{3}$ to open. Sci Signal. 9, pe1.

Thillaiappan, N.B., Chavda, A.P., Tovey, S.C., Prole, D.L., and Taylor, C.W. (2017). Ca ${ }^{2+}$ signals initiate at immobile IP3 receptors adjacent to ER-plasma membrane junctions. Nat Commun. 8, 1505.

Trotman, L.C., Wang, X., Alimonti, A., Chen, Z., Teruya-Feldstein, J., Yang, H., Pavletich, N.P., Carver, B.S., Cordon-Cardo, C., Erdjument-Bromage, H., Tempst, P., Chi, S.G., Kim, H.J., Misteli, T., Jiang, X., and Pandolfi, P.P. (2007). Ubiquitination regulates PTEN nuclear import and tumor suppression. Cell. 128, 141-156.

Tu, H., Wang, Z., and Bezprozvanny, I. (2005a). Modulation of mammalian inositol 1,4,5trisphosphate receptor isoforms by calcium: a role of calcium sensor region. Biophys $J$. $88,1056-1069$.

Tu, H., Wang, Z., Nosyreva, E., De Smedt, H., and Bezprozvanny, I. (2005b). Functional characterization of mammalian inositol 1,4,5-trisphosphate receptor isoforms. Biophys J. 88, 1046-1055.

Uchida, K., Miyauchi, H., Furuichi, T., Michikawa, T., and Mikoshiba, K. (2003). Critical regions for activation gating of the inositol 1,4,5-trisphosphate receptor. J Biol Chem. 278, 16551-16560.

Vandecaetsbeek, I., Vangheluwe, P., Raeymaekers, L., Wuytack, F., and Vanoevelen, J. (2011). The $\mathrm{Ca}^{2+}$ pumps of the endoplasmic reticulum and Golgi apparatus. Cold Spring Harb Perspect Biol. 3.

Vanderheyden, V., Devogelaere, B., Missiaen, L., De Smedt, H., Bultynck, G., and Parys, J.B. (2009). Regulation of inositol 1,4,5-trisphosphate-induced $\mathrm{Ca}^{2+}$ release by reversible phosphorylation and dephosphorylation. Biochim Biophys Acta. 1793, 959-970.

Vazquez, F., Matsuoka, S., Sellers, W.R., Yanagida, T., Ueda, M., and Devreotes, P.N. (2006). Tumor suppressor PTEN acts through dynamic interaction with the plasma membrane. Proc Natl Acad Sci U S A. 103, 3633-3638.

Verbert, L., Lee, B., Kocks, S.L., Assefa, Z., Parys, J.B., Missiaen, L., Callewaert, G., Fissore, R.A., De Smedt, H., and Bultynck, G. (2008). Caspase-3-truncated type 1 inositol 1,4,5trisphosphate receptor enhances intracellular $\mathrm{Ca}^{2+}$ leak and disturbs $\mathrm{Ca}^{2+}$ signalling. Biol Cell. 100, 39-49.

Vervliet, T., Parys, J.B., and Bultynck, G. (2016). Bcl-2 proteins and calcium signaling: complexity beneath the surface. Oncogene. 35, 5079-5092.

Waite, K.A., and Eng, C. (2002). Protean PTEN: form and function. Am J Hum Genet. 70, 829844.

Wang, Y., Pearce, M.M., Sliter, D.A., Olzmann, J.A., Christianson, J.C., Kopito, R.R., Boeckmann, S., Gagen, C., Leichner, G.S., Roitelman, J., and Wojcikiewicz, R.J. (2009). SPFH1 and SPFH2 mediate the ubiquitination and degradation of inositol 1,4,5trisphosphate receptors in muscarinic receptor-expressing HeLa cells. Biochim Biophys Acta. 1793, 1710-1718.

Wojcikiewicz, R.J. (1995). Type I, II, and III inositol 1,4,5-trisphosphate receptors are unequally susceptible to down-regulation and are expressed in markedly different proportions in different cell types. J Biol Chem. 270, 11678-11683.

Wojcikiewicz, R.J. (2004). Regulated ubiquitination of proteins in GPCR-initiated signaling pathways. Trends Pharmacol Sci. 25, 35-41. 
Wojcikiewicz, R.J., Ernst, S.A., and Yule, D.I. (1999). Secretagogues cause ubiquitination and down-regulation of inositol 1, 4,5-trisphosphate receptors in rat pancreatic acinar cells. Gastroenterology. 116, 1194-1201.

Wojcikiewicz, R.J., Furuichi, T., Nakade, S., Mikoshiba, K., and Nahorski, S.R. (1994). Muscarinic receptor activation down-regulates the type I inositol 1,4,5-trisphosphate receptor by accelerating its degradation. J Biol Chem. 269, 7963-7969.

Wojcikiewicz, R.J., and Nahorski, S.R. (1991). Chronic muscarinic stimulation of SH-SY5Y neuroblastoma cells suppresses inositol 1,4,5-trisphosphate action. Parallel inhibition of inositol 1,4,5-trisphosphate-induced $\mathrm{Ca}^{2+}$ mobilization and inositol 1,4,5-trisphosphate binding. J Biol Chem. 266, 22234-22241.

Wojcikiewicz, R.J., Xu, Q., Webster, J.M., Alzayady, K., and Gao, C. (2003). Ubiquitination and proteasomal degradation of endogenous and exogenous inositol 1,4,5-trisphosphate receptors in alpha T3-1 anterior pituitary cells. J Biol Chem. 278, 940-947.

Woods, A., Dickerson, K., Heath, R., Hong, S.P., Momcilovic, M., Johnstone, S.R., Carlson, M., and Carling, D. (2005). $\mathrm{Ca}^{2+} /$ calmodulin-dependent protein kinase kinase-beta acts upstream of AMP-activated protein kinase in mammalian cells. Cell Metab. 2, 21-33.

Yao, Y., Choi, J., and Parker, I. (1995). Quantal puffs of intracellular $\mathrm{Ca}^{2+}$ evoked by inositol trisphosphate in Xenopus oocytes. J Physiol. 482 ( Pt 3), 533-553.

Yoshikawa, F., Morita, M., Monkawa, T., Michikawa, T., Furuichi, T., and Mikoshiba, K. (1996). Mutational analysis of the ligand binding site of the inositol 1,4,5-trisphosphate receptor. J Biol Chem. 271, 18277-18284.

Yu, H., Pak, H., Hammond-Martel, I., Ghram, M., Rodrigue, A., Daou, S., Barbour, H., Corbeil, L., Hebert, J., Drobetsky, E., Masson, J.Y., Di Noia, J.M., and Affar el, B. (2014). Tumor suppressor and deubiquitinase BAP1 promotes DNA double-strand break repair. Proc Natl Acad Sci U S A. 111, 285-290.

Yule, D.I., Betzenhauser, M.J., and Joseph, S.K. (2010). Linking structure to function: Recent lessons from inositol 1,4,5-trisphosphate receptor mutagenesis. Cell Calcium. 47, 469479.

Zhu, Y., Hoell, P., Ahlemeyer, B., and Krieglstein, J. (2006). PTEN: a crucial mediator of mitochondria-dependent apoptosis. Apoptosis. 11, 197-207. 


\section{Figures and legends}

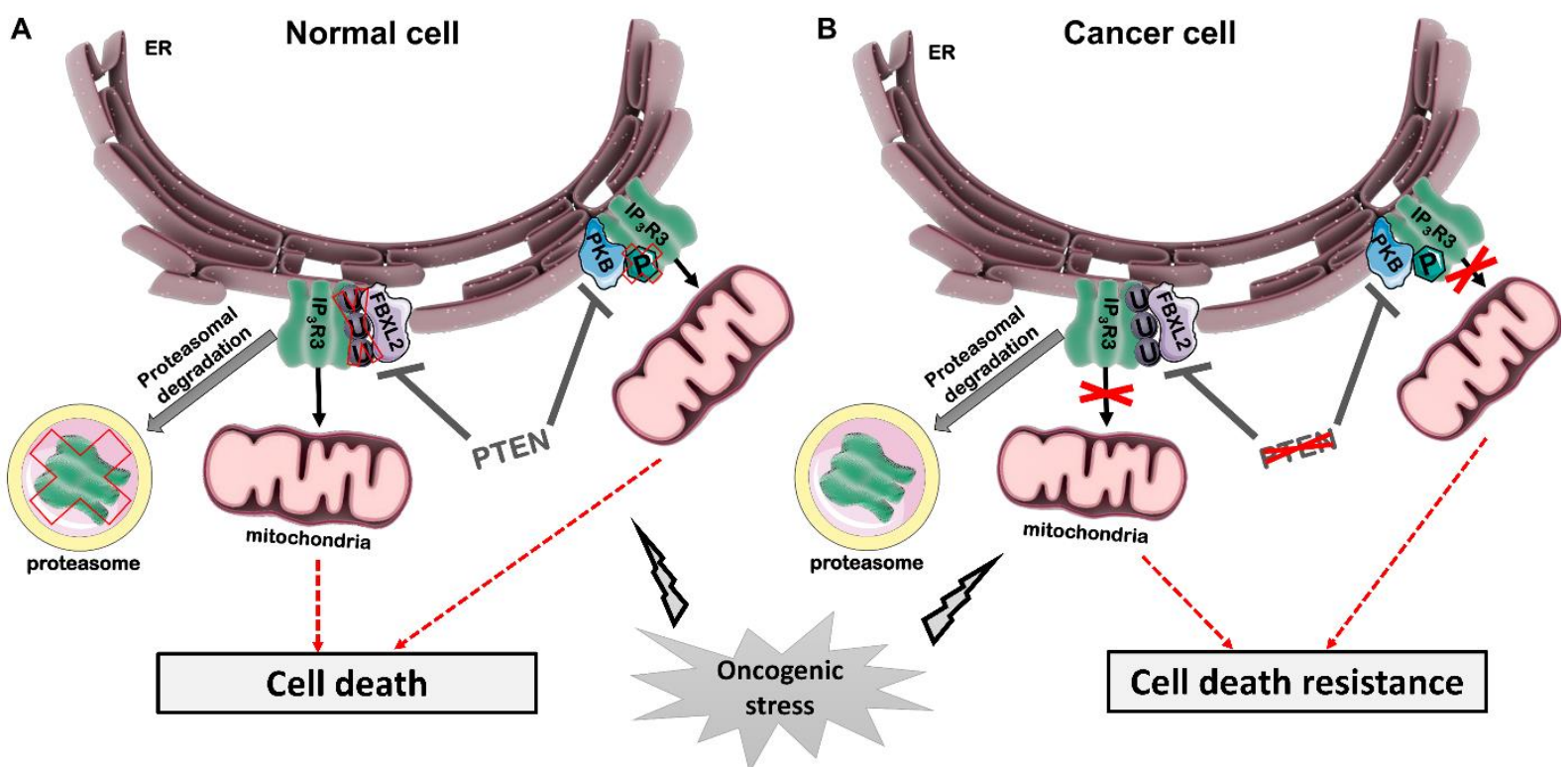

Fig. 1 Modulation of IP $\mathrm{IP}_{3}$ channels by ubiquitination and phosphorylation is a mechanism, exploited by cancer cells to avoid cell death. (A) $\mathrm{IP}_{3} \mathrm{R} 3$ is the most abundant isoform at the MAMs where it facilitates ER-mitochondrial $\mathrm{Ca}^{2+}$ fluxes. The tight regulation of this process enables adequate cell death sensitivity of healthy cells undergoing genotoxic stress and cell damage, preventing oncogenesis. $\mathrm{IP}_{3} \mathrm{R} 3$ function is modulated by different factors and modifications, among which are ubiquitination (grey, $\mathrm{u}$ ) and phosphorylation (green, $\mathrm{p}$ ). FBXL2 is a protein with a ubiquitin ligase activity, which targets $\mathrm{IP}_{3} \mathrm{R} 3$ and mediates its ubiquitination and subsequent proteasomal degradation. PKB is a kinase which by phosphorylating $\mathrm{IP}_{3} \mathrm{R} 3$ decreases its activity. The tumour suppressor PTEN can compete with and antagonize both, FBXL2 and PKB, thereby blocking the ubiquitination or the phosphorylation of $\mathrm{IP}_{3} \mathrm{R} 3$. In normal cell exposed to oncogenic stress, deubiquitination and dephosphorylation of $\mathrm{IP}_{3} \mathrm{R} 3$ will result in stable and active channel, which will sustain adequate ER-mitochondrial $\mathrm{Ca}^{2+}$ transfer and thereby engaging cell death mechanism. (B) Many cancer types display loss of PTEN expression, enabling FBXL2 and PKB to bind to and modulate the receptor. The ubiquitinated and/or phosphorylated $\mathrm{IP}_{3} \mathrm{R} 3$ will be depredated in the proteasomes or will be inhibited, resulting in impaired ER-mitochondrial $\mathrm{Ca}^{2+}$ fluxes. Exploiting this mechanism cancer cells will avoid cell death in response to genotoxic stress and cell damage. This phenomenon is an early event in oncogenesis, enabling malignant cell formation. 
A

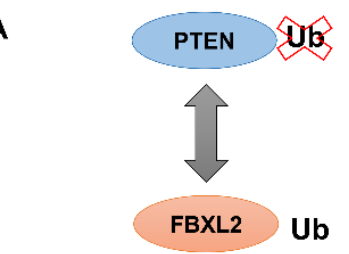

\begin{tabular}{|l|l|}
\hline Ligand-binding domain & Modulatory domain \\
\hline BAP1 Ybs & C-terminal domain \\
\hline
\end{tabular}

B

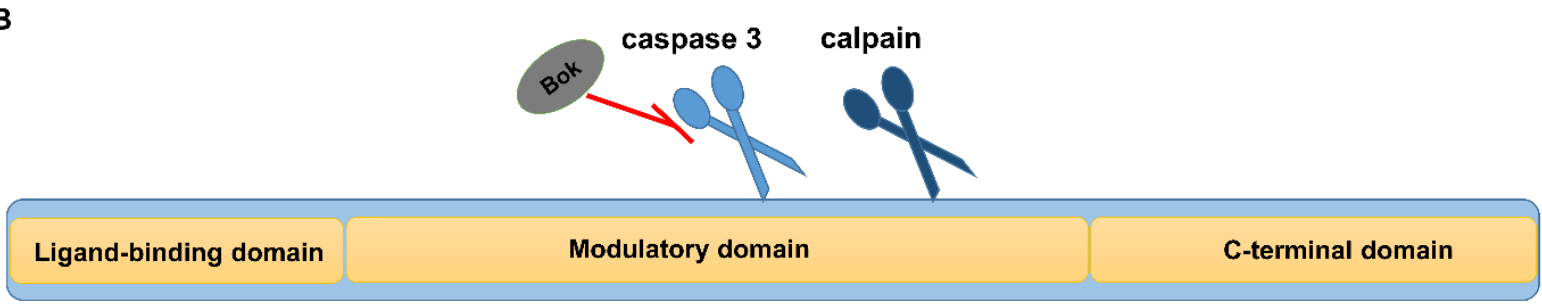

Fig. 2 Linear representation of $I_{3} R$ and the proteins involved in the regulation of its stability. The linear representation of the IP3R is divided in three functional domains: (i) $\mathrm{N}$ terminal ligand-binding domain, (ii) the modulatory domain and (iii) the C-terminal domain. A) Ubiquitination of IP3R. FBXL2 (red) competes with PTEN (blue) for the ligand-binding domain of $\mathrm{IP}_{3} \mathrm{R}$. While FBXL2 interaction with the receptor results in $\mathrm{IP}_{3} \mathrm{R}$ ubiquitination and subsequent degradation, PTEN, independently of its lipid/protein phosphatase activity, prevents this process. BAP1 (green) also targets the ligand-binding domain and the binding leads to deubiquitination and thereby stabilization of the receptor. The impact of FBXL2 and BAP1 on $\mathrm{IP}_{3} \mathrm{Rs}$ has been shown for the type $3 \mathrm{IP}_{3} \mathrm{R}$ isoform. B) Protease-mediated cleavage of $\mathrm{IP}_{3} R$. $\mathrm{IP}_{3} \mathrm{Rs}$ are targets of caspase 3 (light blue) and calpain (dark blue), which cleave the receptor within the modulatory domain. Caspase 3-mediated cleavage is counteracted by the binding of Bok to the $\mathrm{IP}_{3} \mathrm{R}$. The impact of caspase 3 and calpain on $\mathrm{IP}_{3} \mathrm{R}$ integrity has been shown for type $1 \mathrm{IP}_{3} \mathrm{R}$ isoform. 